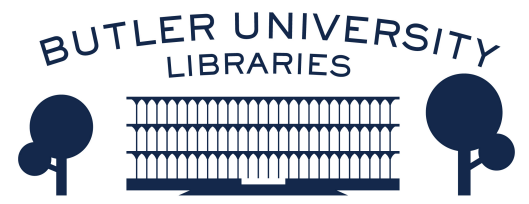

Journal of Hindu-Christian Studies

Volume 31 Celebrating Rāmānuja at 1000: The

Heritage and Promise of the Study of Rāmānuja

in a Christian-Hindu Comparative Theology

Article 31

2018

\title{
Book Review: A.J. Appasamy and his Reading of Rāmānuja: A Comparative Study in Divine Embodiment
}

Arun W. Jones

Emory University

Follow this and additional works at: https://digitalcommons.butler.edu/jhcs

\section{Recommended Citation}

Jones, Arun W. (2018) "Book Review: A.J. Appasamy and his Reading of Rāmānuja: A Comparative Study in Divine Embodiment," Journal of Hindu-Christian Studies: Vol. 31, Article 31.

Available at: https://doi.org/10.7825/2164-6279.1711

The Journal of Hindu-Christian Studies is a publication of the Society for Hindu-Christian Studies. The digital version is made available by Digital Commons @ Butler University. For questions about the Journal or the Society, please contact cbauman@butler.edu. For more information about Digital Commons @ Butler University, please contact digitalscholarship@butler.edu. 
lives, ready to admit what and how we have been accustomed to study, and where and for what reasons we are repeating ourselves. Certainly too, we need always to be ready to welcome younger and fresher contributors to the field as they bring different energies to Hindu-Christian studies. In our era, those of us who are Christian must also keep rethinking our Christology, so as to keep returning to Jesus himself, if we are to have anything to contribute to Hindu-Christian understanding. Francis X. Clooney, SJ Harvard University

\section{A.J. Appasamy and his Reading of Rāmānuja: A Comparative Study in Divine Embodiment. By Brian Philip Dunn. Oxford: Oxford University Press, 2016, xi +315 pages.}

IT is somewhat surprising that one of the giants of Indian theology from the middle half of the $20^{\text {th }}$ century has, since his death, been quite quickly forgotten or deemed irrelevant in theological circles and conversations. Such has been the fate of A. J. Appasamy (18911975), a prominent theologian and bishop of the Church of South India. The reasons for his neglect will be discussed later, but Brian Dunn's rich and perceptive study of Appasamy, which is capped by the author's own constructive exegetical and theological work, should cause comparative and Christian theologians to reexamine the thought of the intellectual pioneer.

Dunn begins his work with an introduction to the life and thought of Appasamy. He was born into a Tamil Christian family; however, his parents had radically different understandings of the faith. His father, a convert from a Shaiva devotional background, wanted to preserve the ties between his Hindu upbringing and his adopted religion. It was the senior Appasamy who impressed upon his son "the need for a truly Indian Christianity" which required an "immersion in classical Hindu literature" (13). His mother, on the other hand, was quite conservative in her religious views, "and believed implicitly that all those who were not of the Protestant faith . . . were heading directly for hell" (13).

The son lived with this double inheritance all his life, on the one hand exploring and mining the Hindu tradition to craft a reinterpretation of Christianity for the Indian context, and on the other hand being deeply wedded to his inherited Anglican tradition. Appasamy's multifaceted hybridity proved to be a source of both great creativity and great misunderstanding, as Dunn skillfully argues with the use of Homi Bhabha's theoretical insights. Appasamy was educated at Madras Christian College, Hartford Theological Seminary and Harvard before going to Oxford where, in 1922, he completed a DPhil under the supervision of Canon B. H. Streeter, writing a dissertation entitled "The Mysticism of Hindu Bhakti Literature: Considered Especially with Reference to the Mysticism of the Fourth Gospel." The gospel of St. John was to Appasamy "the source text for Christian bhakti, 'India's Gospel”' (15). It was also at Oxford that, under the deep influence of Rudolph Otto, he developed his interest in Ramanuja, which "would eventually culminate in 1930's India's Religion of Grace and Christianity Compared and Contrasted' (21). When he returned to India in 1923 after a time in Marburg, Appasamy joined other 
Indian theologians such as Vengal Chakkarai and Pandipeddi Chenchiah in creating Christian theologies that were drawn from Indian religious and philosophical sources. In 1932 he was ordained an Anglican priest, and worked for church union in India. He was consecrated bishop of the Church of South India in 1950, serving in Coimbatore until his retirement in 1959. Appasamy continued to write pastorally and theologically into the 1970s.

The second chapter of Dunn's work deals with issues of methodology. Using Alasdair MacIntyre's categories of Encyclopedia, Genealogy, and Tradition for pursuing philosophical and theological inquiry, as well as the work of Francis X. Clooney, Dunn argues for the integrity and importance of the field of comparative theology in the academy today. This argument is to counter those scholars who would discredit theology in favor of secular religious studies, confining the former to seminaries. Dunn ends the chapter by showing how theological inquiry as "a kind of reasoning about ultimate concerns as referenced to and rooted in traditionally recognized sources of religious revelation and authority" (70) is also practiced in Hindu religious traditions.

The following two chapters deal with Appasamy's theological work. Chapter three explores the first decade (1922-32) of his oeuvre, as he interpreted St. John's gospel in light of Rāmānuja's philosophy and theology. The main themes of these years were the indwelling of God in the universe and the Incarnation. Such themes brought on criticisms from various quarters, especially the Gurukul Theological Research Group that was led by Swedish missionaries, who accused Appasamy of having a "panentheistic view" (94) and "no Atonement or Redemption in [his] theology" (119). The chapter helpfully clarifies Appasamy's true position, and demonstrates that he was, in many ways, simply using the theology of his Anglican teachers and tradition in his reading of St. John's gospel, even as he also employed terms and ideas to be found in Rāmānuja. The chapter closes with a discussion of Appasamy's "somewhat surprising" (130) use of the term Avatāra for the Incarnation. Chapter four concerns itself with the development of Appasamy's thought from 1933 to 1950. In these years he turned to important topics that he had earlier neglected, namely his understanding of the Holy spirit and, following that, of the Trinity. Again, Appasamy explains these using terminology from Rāmānuja, although again his thinking has been deeply influenced by his Anglican heritage. With his ordination in 1932, Appasamy also turned more deliberately to discussion of the Sacraments, and following the lead of thinkers such as Canon Quick developed a sacramental view of the world (163). The chapter ends with topics pertaining to ecclesiology - Appasamy's view of the church as the body of God, and his work for a united South Indian church.

The fifth chapter critically examines Appasamy's reading of Rāmānuja, in order to assess how the former actually used the latter: "what exactly has he learned from Rāmānuja? How has he allowed Rāmānuja's tradition to help him 'rethink' his 'fundamental ideas'?" (181). The answers are varied. Interestingly, the Bishop referred to Rāmānuja far more frequently in his earlier work than in his later. Part of this had to do with the topics he was covering: the more his theology became concerned about Anglican tradition and practice, the less use he had for the Indian philosopher theologian. Yet Appasamy also suffered from his own restricted vision: he "seems to have missed or deliberately 
ignored” Rāmānuja's “tradition-specific realities ... in his reading of the Ācārya" (182). So the chapter ends with an investigation of Ramanuja's theology and philosophy in his sectarian and temple-based context. Dunn's final chapter develops his own "Christological Reconstruction" of the Gospel of John. He does this not "on the basis of 'Rāmānuja's philosophy," but by rereading John after a close reading of Appasamy and Rāmānuja (229).

Brian Dunn has produced a very well argued and compelling investigation of A. J. Appasamy's theology. Dunn is clearly irritated by the bishop's detractors who "have entirely misread him if indeed they have even read him at all" (180). However, Dunn's defense is not polemical: he discusses weaknesses and flaws in his subject's work. Dunn's own constructive project, a theological rereading of John's gospel, is fascinating, although it tends to ignore tensions within the book. The main disagreement I have - and it is a minor one regards the reasons for the current neglect of Appasamy. Dunn, following Homi Bhabha, lays the blame at the feet of colonial attitudes to Indian theology. However, contemporary criticisms of so-called "brahminic" Christian theologies do not care about what Swedish Lutheran missionaries said in the 1950s. Rather, the criticisms arise from Dalit and Tribal theologies (43). Until the logjam created by pitting Dalit against brahminic Christian theologies is disrupted, theologians such as Appasamy will continue to be disregarded, much to the detriment of Indian Christianity, as well as Hindu-Christian comparative theology.

Arun W. Jones

Emory University

\section{Body Parts: A Theological Anthropology. By Michelle Voss Roberts. Minneapolis: Fortress Press, 2017, xlvii + 181 pages.}

TO conduct solid comparative scholarship requires clarity in purpose, an authoritative deftness with the nuances of two different religious systems, and a writing style that can create a bridge of understanding for its intended audience. Voss Roberts has excelled at all of these markers in her latest book, Body Parts: A Theological Anthropology, all while broadening commitments to inclusivity by centering feminist, ecological and disability studies' perspectives.

The primary intention of her work is to reembody the imago Dei and trace out some of the implications of making this shift within Christian theology. Going beyond the explicit goal of decentering mind and reason as the dominant lenses employed by theologians when interpreting the imago Dei (xx-xxi), Voss Roberts works to upend the underlying dualism and hierarchies of body-mind constructions of personhood $(13,86)$ and between humans and creation (134) through her innovative engagement with her interlocutor, Abhinavagupta $\left(10^{\text {th }}-11^{\text {th }}\right.$ century), a Hindu philosopher within a branch of Kasmiri non-dual Saivism.

As a theological anthropology, the emphasis lies in the effects of the imago Dei metaphor on human beings as they see themselves as a reflection of God. For those unfamiliar to this genre of constructive theology, this volume does not involve the typical methods of fieldwork and interviews known to the discipline of anthropology, but 